\title{
Instructional Planning Modifications to Meet Social Distancing Requirements: Secondary and Post-Secondary Options
}

\author{
Trina Johnson Kilty * (D), Andrea C. Burrows $(\mathbb{D}$, Dane Christoffersen, Kevin Thomas Kilty, Kate Muir Welsh, \\ Shawna McBride $\mathbb{E}$, Philip Bergmaier, Christian Bitzas and Cierra Rainey \\ School of Teacher Education, University of Wyoming, Laramie, WY 82071, USA; \\ Andrea.Burrows@uwyo.edu (A.C.B.); dchris20@uwyo.edu (D.C.); kkilty1@uwyo.edu (K.T.K.); \\ kmuir@uwyo.edu (K.M.W.); SMcBride@uwyo.edu (S.M.); pbergmai@uwyo.edu (P.B.); cbitzas@uwyo.edu (C.B.); \\ crainey1@uwyo.edu (C.R.) \\ * Correspondence: tkilty@uwyo.edu
}

check for

updates

Citation: Kilty, T.J.; Burrows, A.C.; Christoffersen, D.; Kilty, K.T.; Welsh, K.M.; McBride, S.; Bergmaier, P.; Bitzas, C.; Rainey, C. Instructional Planning Modifications to Meet Social Distancing Requirements: Secondary and Post-Secondary Options. Educ. Sci. 2021, 11, 217. https://doi.org/ 10.3390/educsci11050217

Academic Editor: Palitha Edirisingha

Received: 31 March 2021

Accepted: 1 May 2021

Published: 5 May 2021

Publisher's Note: MDPI stays neutral with regard to jurisdictional claims in published maps and institutional affiliations.

Copyright: (C) 2021 by the authors. Licensee MDPI, Basel, Switzerland. This article is an open access article distributed under the terms and conditions of the Creative Commons Attribution (CC BY) license (https:/ / creativecommons.org/licenses/by/ $4.0 /)$.

\begin{abstract}
Secondary and post-secondary science and engineering educators share common class arrangements with both a laboratory and lecture component, coordinating both components so they build upon each other to create meaningful learning experiences. The COVID-19 pandemic forced educators to convert lectures and exams to online delivery. Doing so came with trade-off decisions about sacrificing laboratory experience goals of hands-on practice, problem-solving, and learning concepts at a deeper, tactile level. Due to rapidly changing conditions, educators faced course redesign to accommodate social distancing and virtual learning requirements. In this study, a team of undergraduate college students including one secondary science preservice teacher planned a set of lessons for STEM outreach to a K-12 audience. The team faced challenges in planning meaningful learning experiences in the face of COVID-19 uncertainty. Options for secondary and post-secondary educators to consider are provided in this article.
\end{abstract}

Keywords: COVID-19 instructional response; instructional planning; preservice teachers; STEM integration; in-service teachers; undergraduate research; flexible teaching

\section{Introduction}

Science and engineering educators at both secondary and post-secondary level share a common class setup as one having both a laboratory and lecture component [1]. Educators must coordinate the components of a course (lecture, discussion, laboratory experience, homework, projects, and exams) so that they build upon each other to create a holistic experience that works for all students and fits the confines dictated by term length, school breaks, and standardized testing [1,2]. The COVID-19 pandemic caused unprecedented challenges in science and engineering instruction. Educators were forced to react quickly, converting lectures and exams to a remote format, and perhaps cutting out lab components altogether. This was necessary as physical facilities closed, but it often came at the price of not meeting long-established laboratory experience goals of hands-on practice, problemsolving, and learning content at a deeper, more tactile level [3].

By the summer of 2020, many educators found themselves in a perplexing situation: there was time to plan for the fall term, but the social-distancing conditions of that term were still widely unknown. How, then does an educator open this lock, to plan for adaptations and redesign contingent on developing local conditions and likely to change at any time with little warning? The key is that educators must prioritize delivery methods according to purposefully chosen learning objectives in line with preferred instructional strategies.

The authors of this study wished to explore and describe the process of planning instruction under the unusual circumstances of the global COVID-19 pandemic. How does a (preservice or in-service) K-12 science and/or engineering educator prepare lessons 
for a broad spectrum of delivery modes? Did educators explore the trade-offs of each given the lesson goal? Although researchers have reported on teaching and learning experiences [4] and institutional responses at the onset of the pandemic [5], there is a lack of understanding about how teachers began to plan for instruction as the pandemic continued. The authors seek understanding of how teacher educators would approach the instructional planning process. This study tracked one team, consisting of undergraduate college students including one preservice science teacher, who participated in a grantfunded project Learning to Integrate Fundamentals through Teaching (LIFT). The purpose of this study was to describe how the team responded to the challenge of planning for a series of outreach-style minilessons to deliver to a K-12 student audience.

\subsection{Traditional Instructional Planning Process}

The process of planning for instruction historically has been careful, thoughtful proactive decisions and actions meant to effect permanent, meaningful changes in student outcomes. A typical, pre-pandemic instructional planning process often began with a set of learning goals, and one task was to determine how to meet learning goals using appropriate technology and delivery methods [6]. A typical integration of instructional technology may have been to adapt and add online or digital components to a traditional face-to-face course, thereby changing delivery to include technology [7]. Selection of course components to adapt was made according to the delivery mode and technology that may best accomplish learning objectives targeted toward meeting learner needs [8]. Course planners had options of mixed/hybrid delivery that includes components of in-person and virtual activities implemented together, enhanced in-person courses with some online components, or asynchronous online courses, which included activities meant to establish a learning community, such as threaded discussion boards [9]. Planning may have included conducting what instructional designers term a needs analysis, in which information about prior knowledge, motivation, interest, and engagement of students is collected and analyzed, formally or informally $[7,8,10]$. Prior to the pandemic, asynchronous, fully online course delivery modes typically were designed under the assumption students would not be able to meet synchronously or in-person. Other delivery modes accommodated students and educators meeting in-person informally or formally, student-initiated study groups, student-teacher conferences and feedback sessions, and presentations delivered synchronously.

The educator's task was (and still is) to plan the instruction, focusing on pedagogical content knowledge, instructional strategies, and assessment. The instructional planning process encompasses:

- Decision of course delivery mode (e.g., online, in-person)

- Decision of instructional technology integration (pedagogical technology such as Zoom, learning management system, etc.)

- Decision of content (e.g., applying pedagogical content knowledge, incorporating content and learning activities, assessment of learning, etc.).

During the planning process, educators may focus on constructivist learning through authentic learning activities, cooperative and collaborative learning, learner-learner interaction in pairs or groups, and synchronous or asynchronous class meetings [11]. This attention to learning spaces considers the learning goals and the needs of students to interact and learn socially. The process is iterative under the assumption that changes to future course offerings may be made according to student learning outcomes, course evaluations, and/or educator reflective practice rather than a reaction to outside events.

The process of integrating technology is thoughtful, reflective, and time consuming. One researcher estimates up to nine months to fully redesign a course, including quality control checks [12]. To provide an example to illustrate the rationale for the lengthy planning time, some researchers [9] suggest six aspects of synchronous technology to consider before choosing to integrate technology such as web conferencing, including facial expressions, voice nuances, visual and verbal feedback, collaboration, support from the instructor and class, and socialization. A clear option is to blend or incorporate 
other technologies to incorporate all the desired aspects of an in-person class and fulfill student learning needs in an efficient, cost-effective manner [9]. Many secondary and post-secondary educators welcome the feedback and support from course designers in navigating this decision process.

Unfortunately, the unexpected and severe onset of the pandemic disrupted the typically thoughtful and sometimes lengthy planning process and added complexity. Entire institutions and every course needed to quickly transition to remote, online learning, regardless of the educator's prior experience and comfort level teaching with technology. In many cases, the educator faced a steep learning curve with technology and course delivery options. As a result of the sudden and significant changes to all courses during the onset of the pandemic, many educators were left without feedback and support as they adapted courses in response to an outside, unprecedented world event. Moreover, the typically lengthy course redesign process was abbreviated. The standard instructional planning process may have been of limited use during the COVID-19 pandemic because of a variety of reasons including (a) the short time frame-all courses needed to be redesigned practically overnight; (b) the uncertainty of whether the redesign was temporary and how temporary (i.e., rapidly changing conditions); (c) all courses had to be delivered virtually and remotely without any accommodation for in-person activities due to social distancing; and/or (d) all courses regardless of program requirements needed to have the same delivery format, often using the learning management system and/or web conferencing software that the institution recommended or mandated.

A common course delivery mode adopted during the COVID-19 pandemic included synchronous online use web conferencing technology (e.g., Zoom). A synchronous online course may benefit from interactivity and participation from all students [13]. Researchers recommend providing opportunities to communicate with others and build a learning community $[14,15]$. In addition, researchers have shown prerecorded delivery content such as podcasts to be effective in delivering resources in the field and in the laboratory $[16,17]$. However, educators may need to scaffold the process of building an online learning community, model good participation, manage online discussions to set limits, yet generate and maintain interest, and promote a welcoming, inclusive atmosphere [13]. These aspects of online learning spaces may be unfamiliar to educators and must be internalized and practiced by them in addition to teaching course content.

\subsection{Informal Instruction and Planning}

Because the LIFT project incorporated both traditional teaching aspects (such as lesson planning) and informal aspects (such as connected lessons separated over large time spans), a brief review of informal practices is in order. There are multiple studies that showcase aspects of informal instruction such as the use of virtual spaces [18], teacher leaders [19], creativity [20], impacts on pre-collegiate teachers [21], novice teachers [22], university collaborative approaches [23], and many others. One particularly interesting study [24], which predates the pandemic, called for clarity surrounding formal and informal learning. The authors stated (p. 130), "We argue that in order to fuse informal and formal learning, mLearning designers need to offer more clear definitions of the concepts 'formal' and 'informal'; they need to omit some design aspects to the learners themselves, or to offer a design in form of a learning path that students themselves can customize according to their learning habits, routines, and preferences."

Although the article by [24] focuses on mobile learning, the lessons are applicable to a variety of delivery modes. [24] speak to the study that is described here in that they call on three distinctive characteristics of mobile learning (authenticity, collaboration, and personalization) along with sub-categories of situatedness, contextualization, conversation, data sharing, customization, and agency. These aspects were considered in the LIFT project, although some of them were implicitly considered. As [24] pointed out, aspects relating to informal learning are positive. They offered several implications for sustainable mobile 
learning including clear definitions and explanations of concepts, learner control of relevant design aspects, and learner customization of a path of habits, routines, and preferences.

The authors of this study in the LIFT project realized although informal spaces are perceived as positive there are still multiple aspects of informal spaces that necessitate more formal and traditional planning and implementing. The authors did expect and communicate to the LIFT team that they define what they wanted to teach (including what, why, and how), control the options for pre-collegiate students to learn, and create routines for the team that could be replicated with the pre-collegiate students.

\subsection{Setting and Context of Study}

The LIFT grant-funded project formed undergraduate interdisciplinary teams from science, technology, engineering, and mathematics (STEM) as well as education. The team selected a topic of interest to research, design, and build a data collection device (payload) that integrated all disciplines of STEM (also called integrated STEM) to gather data answering a scientific question or solving an engineering problem related to the topic of interest. The main element of LIFT is that the question or problem is answered by collecting data on sensors attached to a high-altitude balloon. Undergraduates attach the payload to a high-altitude balloon, analyze the results, and communicate findings. Although balloon projects have been used for scientific research and projects have included secondary and postsecondary students for years [25-28], the pre-determined projects often collect data related to temperature and other atmospheric characteristics $[29,30]$. The LIFT project differs with undergraduate participants choosing ill-defined questions and problems with is consistent with authentic science practices [31]. The undergraduates that form these interdisciplinary teams design and teach lessons and activities as STEM outreach to $\mathrm{K}-12$ students.

In this project, a team of three undergraduates (physics, education, and computer engineering majors) worked with secondary students in eighth grade (typically 13-14 years old) to design an experiment in radio occultation that gathered data on sensors attached to a high-altitude balloon. During the spring semester of 2020, the team designed and planned a set of lessons and activities, aligned with state science standards, which encouraged eighth grade students to join the team in hands-on, scientific inquiry. The following semester, the team planned to implement the lessons and activities with eighth grade students, include them by launching the high-altitude balloon from the school grounds, and analyze and interpret the results that they and the eighth grade students retrieved. However, as summer 2020 progressed, the team faced uncertainty about fall 2020 visits to the classroom.

In this study, the focus was on one minilesson delivered in an outreach format to an eighth grade (at a public middle school with students aged 10 to 14 years) science class, and how three undergraduates developed that lesson with the added challenge of planning how to implement that lesson under a variety of scenarios determined by the COVID-19 pandemic constraints. While there is literature surrounding how to effectively develop online course structures, they often presume sufficient time for creation [32], and rarely focus on preservice and student teachers [33]. This research study fills a gap in the literature about rapid planning and course changes to online formats, rather than instructional planning with time for careful attention to organization of materials, by novice teachers. The authors of this study pursued the following research question:

Research Question: How does an interdisciplinary undergraduate grant team, including a late-term preservice $\mathrm{K}-12$ teacher, prepare science outreach lessons for a broad spectrum of potential delivery modes?

\section{Materials and Methods}

This study was a qualitative case study that took place at a research university in the United States (U.S.). The purpose of this study was to describe both the process (planning) and product (implementation) of the minilesson for STEM outreach to eighth grade students at a public middle school in the U.S. The authors of this study functioned 
as researchers in a detached participant role. The theoretical perspective was interpretivist and focused on description [34]. The nature of the case study was instrumental by studying undergraduates to interpret how educators reacted to the planning challenges caused by the pandemic [35]. The case was bounded by one university in the U.S., with a team of three undergraduate students including one preservice secondary science teacher planning and implementing a minilesson to a group of $\mathrm{K}-12$ students.

The participants in this study were a team of three undergraduate college students: a physics major (female), a computer engineering major (male), and a preservice secondary physics teacher education major (male). The project also aimed to foster integrated STEM learning by interdisciplinary work to prepare these undergraduates for their future career [36,37]. The undergraduate college student participants consented to participate in this study, which was approved by IRB. The eighth grade students they worked with, as well as the partner teacher and school setting, were not included in the study. The team developed and taught outreach lessons to students using hands-on, authentic scientific inquiry, through a radio occultation experiment with lessons aligned to national physical science standards [31,38]. The created lessons provided background knowledge about meteorology, GPS technology, and weather prediction by radio occultation, a method by which satellite signal diffraction is analyzed to give information about the atmosphere through which it passes. The team followed the balloon launch experiment by discussing results with students.

The team translated the radio occultation project into lessons and activities appropriate for eighth grade students to engage in STEM data collection, witness the launch, help analyze the results, and participate in sense-making. They aligned the topic with physics concepts in physical science national and state standards [38]. The partner eighth grade in-service teacher at the middle school scheduled three class periods of instruction for the undergraduate team to conduct the outreach activity. The team planned the first time-period to provide background knowledge about meteorology. The lessons fostered an understanding of GPS technology. The second time-period lesson established foundational knowledge for the subject of the experiment: weather prediction through radio occultation. This is the method by which a satellite signal's refraction is analyzed to give information about the atmosphere through which it passes, thereby supplying data for weather forecasting. The launch of the balloon itself was an additional activity not counted as a class time-period. After the balloon launch, the team planned the third and final time-period to share results and discuss with $\mathrm{K}-12$ students how to analyze and make sense of the results as well as what improvements and next steps in research might be.

Data includes field notes and observations of the process of planning, reflections of the participants about the planning process, and observations of the implementation of the lessons. Lesson plans and outlines of scenarios are the products of this study along with participant reflections as noted in final interviews. Table 1 shows the original outreach teaching plan according to topic and class periods.

Once satisfied with the plans, the team considered how the outreach activities would fit into school reopening scenarios. Many public schools did not solidify school reopening plans until August 2020. Therefore, the design process was somewhat speculative, outlining many paths given a continuum of possible classroom scenarios. Table 2 showcases how the team adapted lessons for several social distancing scenarios.

The first scenario presented a normal class time-period with the entire class present and teaching in-person. The team faced a unique second scenario due to school policies regarding visitors; they prepared for this scenario by sending lesson and activity plans to the partner teacher to facilitate while they participated virtually. The third scenario of in-person meeting called for half the class to attend school on alternating days for reduced capacity. Remote synchronous is set up like in-person but takes place at home; everyone logs onto a program such as Zoom at the same time to hold a verbal discussion. A remote asynchronous scenario is one in which all lessons and instructions are prerecorded so students view lessons and contribute to a written discussion thread with a time lag. 
Table 1. Central Topic and Arrangement into Modules.

\begin{tabular}{|c|c|c|c|}
\hline Learning Activity & Topic 1: Weather & Topic 2: GPS/Occultation & $\begin{array}{c}\text { Topic 3: Launch and } \\
\text { Follow Up }\end{array}$ \\
\hline $\begin{array}{l}\text { Content Delivery: guiding } \\
\text { question, topics }\end{array}$ & $\begin{array}{l}\text {-weather prediction } \\
\text {-weather balloons }\end{array}$ & $\begin{array}{l}\text {-How can you describe a point } \\
\text { in space? } \\
\text {-distance from } 3 \text { other points } \\
\text {-sound occultation demo }\end{array}$ & $\begin{array}{l}\text {-Why are high-altitude } \\
\text { balloons useful? }\end{array}$ \\
\hline Experiments & $\begin{array}{c}\text {-hot/cold water currents } \\
\text {-forming a cloud in a bottle } \\
\text { demo/activity } \\
\text {-fill a balloon by heating } \\
\text { demo/activity }\end{array}$ & $\begin{array}{l}\text {-Triangulation using } 3 \text { strings } \\
\text { represents GPS, end of string } \\
\text { represents satellite, length of } \\
\text { string represents time. } \\
\text {-phasing out a sound wave } \\
\text { (physics toolbox app) } \\
\text {-light wave through } \\
\text { different mediums }\end{array}$ & $\begin{array}{l}\text {-launch of high-altitude } \\
\text { balloon to measure } \\
\text { GPS occultation }\end{array}$ \\
\hline Discussion/sense making & $\begin{array}{l}-3 \text { factors in weather } \\
\text { prediction: temperature; } \\
\text { pressure; humidity. } \\
\text {-Other items: data resolution; } \\
\text { high altitude measurements; } \\
\text { lots of measurements }\end{array}$ & $\begin{array}{l}\text {-radio occultation as a } \\
\text { forecasting tool } \\
\text {-air density cause phase shift } \\
\text {-temperature, humidity, pressure } \\
\text { can be derived }\end{array}$ & $\begin{array}{l}\text {-data analysis } \\
\text {-limits of occultation } \\
\text {-benefits of occultation } \\
\text {-future experiments or } \\
\text { other applications }\end{array}$ \\
\hline
\end{tabular}

Table 2. Social Distancing-Possible Adaptations.

\begin{tabular}{|c|c|c|c|c|}
\hline $\begin{array}{l}\text { Social Distance } \\
\text { Conditions }\end{array}$ & Content Delivery & Experiments (Labs) & $\begin{array}{c}\text { Experiments: Launch } \\
\text { Itself }\end{array}$ & $\begin{array}{l}\text { Discussion/Sense } \\
\text { Making }\end{array}$ \\
\hline $\begin{array}{c}3 \text { days in classroom, } \\
\text { everyone present }\end{array}$ & $\begin{array}{l}\text { In-person delivery-mix } \\
\text { of lecture, review, data } \\
\text { analysis, and } \\
\text { prerecorded, narrated } \\
\text { videos }\end{array}$ & $\begin{array}{l}\text { In-person delivery with } \\
\text { students in small } \\
\text { groups; demo to } \\
\text { whole class }\end{array}$ & $\begin{array}{l}\text { Launch: In-person } \\
\text { delivery with students } \\
\text { standing at a distance } \\
\text { from balloon as it inflates } \\
\text { (typical procedure) }\end{array}$ & $\begin{array}{l}\text { In-person discussion } \\
\text { and analysis with } \\
\text { whole class or } \\
\text { small groups }\end{array}$ \\
\hline $\begin{array}{l}\text { All students in } \\
\text { classroom, remote } \\
\text { LIFT team }\end{array}$ & $\begin{array}{l}\text { Teacher plans for } \\
\text { lecture, analysis, } \\
\text { prerecorded videos }\end{array}$ & $\begin{array}{l}\text { Teacher plans for } \\
\text { facilitation of students } \\
\text { in small groups; } \\
\text { prerecorded demo }\end{array}$ & $\begin{array}{l}\text { Launch: In-person with } \\
\text { limited balloon launch } \\
\text { witnesses; smaller group } \\
\text { stands further back }\end{array}$ & $\begin{array}{l}\text { Students in-person, } \\
\text { facilitators participate } \\
\text { via Google Meet, } \\
\text { teacher displays } \\
\text { Google Meet session } \\
\text { and participates }\end{array}$ \\
\hline $\begin{array}{c}\frac{1}{2} \text { capacity classroom, } \\
\frac{1}{2} \text { remote, } \\
\text { alternating days }\end{array}$ & Prerecorded videos & $\begin{array}{l}\text { Repeat in-person small } \\
\text { group experiments } \\
\text { with both student sets }\end{array}$ & $\begin{array}{c}\text { Augmented reality } \\
\text { launch; one group } \\
\text { witnesses in-person; the } \\
\text { other group watches } \\
\text { launch video }\end{array}$ & $\begin{array}{l}\text { Repeat in-person small } \\
\text { group discussions and } \\
\text { data analysis twice }\end{array}$ \\
\hline $\begin{array}{l}\text { Remote, synchronous } \\
\text { via Google Meet }\end{array}$ & $\begin{array}{c}\text { Google Meet } \\
\text { conversations, } \\
\text { prerecorded videos }\end{array}$ & $\begin{array}{l}\text { At-home experiment } \\
\text { with Zoom instructions } \\
\text { and office hours }\end{array}$ & $\begin{array}{c}\text { Augmented } \\
\text { reality/remote launch via } \\
\text { live stream: students } \\
\text { follow along remotely }\end{array}$ & Google Meet discussion \\
\hline $\begin{array}{c}\text { Remote, } \\
\text { asynchronous }\end{array}$ & Prerecorded videos & $\begin{array}{l}\text { At-home experiment } \\
\text { with prerecorded } \\
\text { podcast instructions }\end{array}$ & $\begin{array}{l}\text { Remote launch (not } \\
\text { necessarily at school site); } \\
\text { students follow along } \\
\text { live or watch later }\end{array}$ & $\begin{array}{l}\text { Prerecorded video; } \\
\text { asynchronous } \\
\text { discussion forum }\end{array}$ \\
\hline
\end{tabular}

Data analysis consisted of triangulation of products, process planning, and observations of multiple meetings and planning sessions. Data to be analyzed included the participant-generated scenario chart, field note observations of meetings throughout the project, field note observations during the implementation of the lessons, and final in- 
terviews with participants after the completion of the project. The authors discussed interpretations of meetings and lesson implementation, ultimately reaching a consensus.

\section{Results}

The task of planning for different reopening scenarios compelled the team to prioritize some instructional components and eliminate others. They prioritized moving content instruction (lectures) to remote delivery online. As undergraduate students who have taken online classes, including after the university pivoted to completely remote in Spring 2020 in response to the COVID-19 pandemic, they have used tools to convey information online, such as videos which combined lecture footage with digital graphics. The transition may even be considered an improvement; the team found they could edit and perfect content before posting and students could repeat and pause as often as desired. They made plans to integrate instructional technology such as podcasts, which researchers have shown effective in delivering resources in the field and in the laboratory [16,17], but ultimately settled on prerecorded videos that students could watch by following links. They did not expect these formats to pose a challenge to eighth grade students whose curriculum were also affected by the pandemic and therefore have similar previous experience.

Based on the preservice teacher's education and experience, the team decided that a crucial use of instructional time was sense-making through discussion-based learning $[15,18]$. They felt it was important to include interactive discussion and sense-making conversations in every delivery scenario as researchers recommend providing opportunities to communicate with others and build a learning community [14,15]. In planning for asynchronous instruction, they chose online discussion boards to monitor learning.

Experiments (labs) presented a complicated problem to solve. Given the middle-school audience and the learning goals, the team decided that with minor adjustment, experiments could be completed from home if adequate instruction were given. They recognized the challenge, teaching remotely, of how to effectively guide experiments middle school students complete at home. The experiments must be safe, relatively inexpensive, and reasonably clean. Instructions need to be clear, especially if delivered asynchronously. This brings a disadvantage, however, in that students cannot ask questions and get immediate feedback. Some students may be quite disadvantaged with an at-home lab scenario in terms of equity and access issues, and although the issue remains deeply concerning, it goes beyond the scope of this paper. The team thus planned for all school delivery options.

The team considered additional lab options appropriate for social distancing requirements. The actual balloon launch to collect data showcases how an actual experiment (lab) could be altered to fit the continuum from in-person to remote. In the past, launches had taken place in an open area near the school. Students walked out to witness undergraduates fill the balloon with helium, attach the payload, and release the balloon. Sometimes students board a bus and accompany the university group to retrieve the payload after the balloon bursts and returns to the ground. Adaptations for social distancing regarding the launch began with an in-person scenario. The balloon, as it inflates, poses a slight safety risk of hitting someone if it wobbles in the wind. Therefore, even in normal times students are asked not to approach the balloon too closely. Stricter social distancing requirements called for augmented reality and remote access. Fortunately, two augmented reality applications accompany the balloon payload: a satellite communication device (SatCom) and a set of HD cameras. The SatCom transmits real-time GPS information (latitude, longitude, and altitude) and atmospheric data (temperature, air pressure, humidity, and wind speed) directly to the internet. Using a unique webpage with a real-time mapping interface, interested onlookers could follow the balloon flight virtually [39]. This provided a way to accommodate fewer students witnessing the launch and the possibility that students would not be able to accompany the team to retrieve the payload. Students, from home or from school, were able to view the balloon's path on a map, monitor real-time atmospheric conditions, see where the balloon burst, and locate where the payload landed. Later, after the team retrieved the payload and process the onboard HD video footage, students could 
watch a replay of the balloon's actual journey into the stratosphere [40]. These augmented reality applications afforded the actual balloon launch to still be possible even under the most restricted scenario, in which the team would need to launch the balloon at the university and middle school students must follow along remotely from home. Other examples of online science access can be found in remote telescope observations [41], PhET [42], and others [43].

There are some additional affordances, unique to the LIFT project in this study, that offer students a chance to move into virtual reality. Part of the payload may move data into Google Earth by sending along a Septentrio GPS receiver. It includes data to create a KML file that can be imported to Google Earth. This allows students to see a 3D model on Google Earth of where the balloon went, including allowing side viewing. The Septentrio records highly accurate location and altitude data every second, so it theoretically should transpose a little line of the balloon journey over a model of Earth.

\subsection{Actual Teaching Scenario}

The school where the eighth grade class participated resumed school in fall 2020 under a socially distant scenario. Half of the student body attended two days a week, while the other half attended on the other two days, with Fridays reserved for offering extra assistance. The principal of the participating school initially did not allow visitors into the school during fall 2020. The team therefore chose to offer the lessons in a synchronous remote delivery mode. The partner teacher cooperated with the undergraduate team by communicating via email about the lesson plan, helping to set up the demonstrations, supplying materials and logistics of the learning activities, and training the team on the use of Google Meet, the synchronous delivery platform the school used. Table 3 displays the actual social distancing restrictions the team taught under. Note that the actual scenario closely but not exactly fits one of the possible adaptations described in Table 2.

Table 3. Actual classroom conditions for lessons.

\begin{tabular}{ccccc}
\hline $\begin{array}{c}\text { Social Distance } \\
\text { Conditions }\end{array}$ & Content Delivery & Experiments (Labs) & $\begin{array}{c}\text { Experiments: Launch } \\
\text { Itself }\end{array}$ & $\begin{array}{c}\text { Discussion/Sense } \\
\text { Making }\end{array}$ \\
\hline $\begin{array}{c}\frac{1}{2} \text { capacity classroom, } \\
\frac{1}{2} \text { remote, alternating } \\
\text { days, remote } \\
\text { [blinded] team }\end{array}$ & $\begin{array}{c}\text { Partner teacher plans } \\
\text { for lecture; delivers } \\
\text { prerecorded videos } \\
\text { from team; repeated } \\
\text { lesson twice }\end{array}$ & $\begin{array}{c}\text { Partner teacher plans } \\
\text { for facilitation of } \\
\text { students; delivers } \\
\text { prerecorded demo from } \\
\text { team; repeated } \\
\text { lesson twice }\end{array}$ & $\begin{array}{c}\text { Launch: Everyone } \\
\text { in-person with social } \\
\text { distancing guidelines } \\
\text { (held on Friday when } \\
\text { all students } \\
\text { attend school) }\end{array}$ & $\begin{array}{c}\text { Students in-person, } \\
\text { partner teacher delivers } \\
\text { prerecorded video from } \\
\text { team; repeated } \\
\text { lesson twice }\end{array}$ \\
$\begin{array}{c}\text { [blinded] team: Remote, } \\
\text { synchronous online }\end{array}$ & $\begin{array}{c}\text { Synchronous online } \\
\text { discussion, prerecorded } \\
\text { videos }\end{array}$ & $\begin{array}{c}\text { Synchronous online } \\
\text { discussion }\end{array}$ & & Prerecorded video \\
\hline
\end{tabular}

As planned, the team met remotely with students synchronously online (Google Meet) twice a week to deliver the minilesson to all students (half the students in each alternating day). The lessons proceeded by the undergraduate team logging into Google Meet synchronously but sometimes separately due to quarantine, isolation, etc., at the appointed class period time. The team introduced themselves and turned on their camera and audio. The eighth grade students in the classroom appeared to watch on a large projection screen and be able to hear. When students had a question, they approached the partner teacher's laptop to ensure the undergraduate team could hear them through the laptop microphone. The undergraduate team also prepared videos in which each team member explained scientific or engineering concepts, which were played by the partner teacher using a link. These prerecorded videos appeared to ease the technological challenge of varying bandwidth and static of transmission, and students appeared able to see and hear. The partner teacher conducted demonstrations in the eighth grade classroom. In the case of the GPS/string activity, students participated and moved around the room while the undergraduate team viewed the activity from the laptop vantage point, which 
did not always show the full picture. When the undergraduate team was able to gather, they scheduled time in an unused classroom at the university and turned on the instructor station webcam and microphone. Members of the team used the university classroom whiteboard to explain concepts and focused the cameras on their payload to allow the eighth grade students to observe.

An unexpected development happened with the school principal for the high-altitude balloon launch. The principal allowed the launch to take place on school grounds in a large open field and allowed students to walk out and view the launch, provided social distancing measures were in place. The launch was scheduled for a Friday, a day in which all the students were attending, eliminating the need to launch the balloon live for one half while the other half watched from home. The undergraduate team asked a few eighth grade students to assist with holding the payload and other tasks. The team, especially the secondary science preservice teacher, talked with the eighth grade students and establish a learning relationship, which heretofore had been only through video, by re-introducing himself and asking students questions designed to trigger previous learning and make connections between the minilessons and the actual launch.

\subsection{Reflections on Actual Teaching Scenario}

Table 4 displays quoted reflections from each member of the undergraduate team regarding how they thought the actual teaching scenario compared with their original plans. Every team member mentioned the unexpected, uncertain nature of the COVID-19 pandemic affecting their uncertainty about delivering the lessons and even launching the balloon. Every team member expressed satisfaction with how the lesson and launch ultimately turned out. All names are pseudonyms.

Table 4. Reflections by Undergraduate Team on Actual Teaching Scenario.

\begin{tabular}{|c|c|c|c|}
\hline Undergraduate Team Member & Met Original Goal? & Challenges? & Successes? \\
\hline Gail (physics major, female) & $\begin{array}{l}\text { Even despite the pandemic ... I } \\
\text { don't think it shifted our goal too } \\
\text { much from what we originally } \\
\text { had planned. }\end{array}$ & $\begin{array}{l}\text { I had wanted to, you know, go in and } \\
\text { actually interact with the kids and } \\
\text { get them interested in science, but we } \\
\text { weren't exactly able to. }\end{array}$ & $\begin{array}{l}\text {.. but I think despite all that, it } \\
\text { still went over well. The project } \\
\text { did, and the impact on the } \\
\text { students too, from what I can tell. }\end{array}$ \\
\hline $\begin{array}{l}\text { Glen (computer engineering } \\
\text { major, male) }\end{array}$ & $\begin{array}{l}\text { [Teaching remotely] did make it a } \\
\text { lot harder. [In-person] they could } \\
\text { [have gone] up and look at } \\
\text { [payload] and actually see where } \\
\text { the parts were, what they looked } \\
\text { like, what they did, and we could } \\
\text { have, like, talked to them while } \\
\text { they were looking at it. And kind } \\
\text { of have them look around the box. } \\
\text { Because it's not really fragile, so } \\
\text { they can kind of turn it over and } \\
\text { stuff... I feel like [remote } \\
\text { lessons] did make it a little bit } \\
\text { harder for the students. }\end{array}$ & $\begin{array}{l}\text { I think the prerecorded video was a } \\
\text { lot easier for us. But the bonus of the } \\
\text { in-person is that we kind of had to } \\
\text { prepare for it, and then we were also } \\
\text { able to see like the reactions and get } \\
\text { questions and help the students a lot } \\
\text { more. So, and like in the recorded } \\
\text { videos, you can't really do that. You } \\
\text { kind of just say stuff and then if you } \\
\text { think it will help the students but } \\
\text { really it doesn't, you don't know. We } \\
\text { did have a big lack of questions with } \\
\text { the remote [lesson delivery], which I } \\
\text { guess is another con of going online } \\
\text { and doing it remotely, is you can't } \\
\text { really force students necessarily to } \\
\text { ask questions, so there's that. }\end{array}$ & $\begin{array}{l}\text { When we had to simplify some of } \\
\text { the radio occultation, what it was, } \\
\text { like when you simplify it, it kind } \\
\text { of makes it easier for you to } \\
\text { understand while you're teaching } \\
\text { it ... So like when you're trying } \\
\text { to teach it, you can kind of put } \\
\text { together how to make it simple, } \\
\text { and then it kind of teaches you the } \\
\text { overall concept of it better, I think. }\end{array}$ \\
\hline $\begin{array}{l}\text { Gabe (secondary science } \\
\text { education major, male) }\end{array}$ & $\begin{array}{l}\text { I feel like uh, for the first lesson, I } \\
\text { think that was probably our } \\
\text { weaker of the two lessons. I think } \\
\text { we were relying a bit too much on } \\
\text { the premade videos. I mean, we } \\
\text { had to try it out, right? I mean, I } \\
\text { don't regret trying it out. But I } \\
\text { think in the end that wasn't as } \\
\text { effective as the } \\
\text { synchronous communication. }\end{array}$ & $\begin{array}{l}\text { Well, uh, we didn't really know what } \\
\text { was going on. Um, for most of [the } \\
\text { synchronous lesson]. And I feel like } \\
\text { because of that, the timing was pretty } \\
\text { messed up in some places. Some } \\
\text { classes we had like } 10 \text { min and I just } \\
\text { kind of filled in the time, and some } \\
\text { we had, like a minute at the end to try } \\
\text { to squeeze all the information into. }\end{array}$ & $\begin{array}{l}\text { Teaching experience is always } \\
\text { good. It was a novel experience } \\
\text { too; I had never before taught } \\
\text { very much over remote methods. } \\
\text { And I had never really spent quite } \\
\text { as much time planning out } \\
\text { demonstrations. That was the fun } \\
\text { part of it. }\end{array}$ \\
\hline
\end{tabular}


During interviews and other data collection, each undergraduate participant commented on a different facet of the experience. Gail, the physics major, emphasized how the team persisted with their original learning goal and met success despite setbacks of remote delivery. Glen, the engineering major, examined the trade-offs and analyzed how the hybrid in-person/remote delivery method resulted in learning deficiencies as well as advantages. Gabe, the education major, appreciated the opportunity to try a delivery method that he perceived as new, but lamented the constraints of planning for a single outreach educational experience without opportunity to engage in reflective practice to optimize the lesson. The impacts of the pandemic appeared to recede and be supplanted by the nature of single-encounter outreach lessons preventing careful planning, which includes both iteration and optimization. For future teams or groups, the authors recommend lesson planning with a focus on possible iterations and optimizations.

\section{Discussion and Conclusions}

Overall, the take-away message from this study is that instructional planning should be intentionally deliberate and takes time for option processing. The pandemic forced planning to become reactive, quick, and subject to change, and this shift removed intentional planning time from many early scenarios. What the LIFT team did was take a slow-down proactive approach to plan for multiple scenarios in the upcoming lessons, and that allowed the team a bit more flexibility in the teaching moment. After the lessons, the LIFT team also indicated that they wanted to improve the lesson, either by delivery method or teaching strategy that they thought might have been more effective than what was utilized when teaching. A proactive approach of planning scenarios and then reflecting on teaching effectiveness does not solve the problem of creating all possible teaching options, but it might lessen stress during the moments of teaching. Sharing these optional lesson aspects could be crucial if another pandemic or unexpected event causes another abrupt shift in teaching planning time.

If one contrasts the pandemic response redesign with a traditional course design process, the main difference is that in traditional course design, the course is designed or redesigned for online delivery and activities are designed in advance of the start of the course. In a rapid reformatting scenario, the opposite happens. Activities are not planned until the instructor determines what delivery mode the course needs to transform into, and the delivery mode may change during the course or in the moment, perhaps just before, during, or nearing the end of the activity. Historically, course design has not veered off unexpectedly into a different delivery mode, nor is an online/remote course traditionally defined as a course that switches back and forth depending on health concerns, nor one in which students move in and out of remote and in-person attendance due to quarantine, isolation, etc. The mass uncertainty and unprecedented nature of the pandemic is to blame for an uneven and tentative course design response by institutions of learning. Specifically, with prompting, the LIFT undergraduate team planned for the unexpected remarkably well considering their lack of teaching experience. They kept the original goal in mind as circumstances continued to change. This model can be replicated, and the authors argue should be replicated, and thus was the impetus for this article.

The first author of this study draws from personal experience of planning and teaching a college-level course during fall 2020. She found herself planning for activities to take place in person, but a few weeks later, the institution pivoted to an online start with a transition to in-person learning after eight weeks. In response to rising numbers of COVID-19 cases, instruction was paused for a week in which no one was allowed on campus. The semester ended with a return to online delivery a week earlier than expected. Despite her prior experience with both teaching and instructional design, she felt frustrated and ultimately canceled some learning activities, because in the moment there was not time to change delivery modes so rapidly. In retrospect, she feels that there was a benefit from planning the next course according to possible delivery scenarios, like the LIFT participants in this study did, and it reduced her stress. 
A positive aspect of the COVID-19 pandemic is attention to renewed intentionality in planning and how instructional time should be used. If course designers are unable to assist in a lengthy redesign process, educators then must also concentrate on the structure and planning of the course beyond content and student engagement with the content. Multiple repetitions of redesign options transform into further iterations as educators react to what did not work well the previous semester, and this provides more options to choose from as courses come and go. Publications such as [9] may provide concise guidelines, but repositories of the same lessons taught in multiple formats would be beneficial for educational instructors. For example, if course delivery must change to synchronous online (e.g., Zoom) sessions, educators may have to consider how to model interaction by requiring students to ask questions, turn on cameras and make eye contact, and so forth as discussed by [9], but they might also need to change the lesson aspects to meet learning needs that are not addressed by the aforementioned considerations (such as changing from three to two main content objectives).

Additionally, educators may need to model desired behavior when teaching format changes. As the format changes, strategies for content delivery and student engagement might also take a new form. In this type of environment, planning can no longer solely focus on learning activities, but also encompass the structure of the learning environment in an online setting. Traditional in-person classroom course design focuses on the pedagogy, content knowledge, instructional strategies, and other well researched areas. Switching learning environments creates the need to focus on the infrastructure as well, which is an added burden to educators that in the past have not needed to be adept in this area as well. Taking a preemptive approach to plan alternative instructional delivery combinations for lesson aspects can offer continued flexibility in future course redesign efforts and making in-the-moment, necessary, teaching changes.

The lessons learned from this LIFT research study, center around creating a space for learning-online and in-person, or both, rather than centering around traditional pedagogical content knowledge in traditional or online spaces. The authors' research question asked, "How does an interdisciplinary undergraduate grant team, including a late-term preservice $\mathrm{K}-12$ teacher, prepare science outreach lessons for a broad spectrum of potential delivery modes?" In the spirit of lessons learned, the authors offer the following potential options (or recommendations) for secondary and post-secondary STEM educators planning courses subject to changing formats and social distancing constraints:

(a) Move lecture and content instruction online or into a hybrid scenario using prerecorded videos and podcasts. These can be viewed before, during, or after class depending on the needs of the activity and can be prepared in advance of the course.

(b) Use synchronous class discussions to webinar (e.g., Zoom) or asynchronous discussion format and encourage/require students to ask questions and respond to each other. This promotes interaction and provides a space for community building.

(c) Offer step-by-step instructions for student at-home experiments and activities as soon as possible. Providing resources, such as instructions as soon as they are created is a mechanism to allow maximum student engagement and response time. Since students working at home are often following a non-traditional school schedule, and in a non-traditional school space, providing extra time to engage with materials is of the utmost importance.

(d) Provide access remote STEM learning opportunities (such as remote telescope observations, PhETs, and more) to allow students the time and space to interact with STEM experiences from the place where they are trying to learn.

(e) Apply [24] considerations for authenticity, collaboration, and personalization along with situatedness, contextualization, conversation, data sharing, customization, and agency.

Although the authors offer suggestions, there is no one answer or one uniform way that every educator and every student respond to shifting teaching modalities. Each person has a different set of constraints and all of those must be taken into consideration; thus, instructional adaptations should be previously prepared and fluid for flexible teaching. 
Author Contributions: Conceptualization, T.J.K., A.C.B., and D.C.; methodology, T.J.K., A.C.B.; validation, T.J.K.; formal analysis, T.J.K.; investigation, T.J.K., D.C., C.B., P.B., and C.R.; resources, T.J.K., A.C.B., D.C., K.T.K., K.M.W., S.M., C.B., P.B., and C.R.; data curation, T.J.K.; writing-original draft preparation, T.J.K., A.C.B., and D.C.; writing-review and editing, A.C.B., K.M.W., P.B., K.T.K., S.M., C.B., and C.R.; visualization, T.J.K. and A.C.B.; supervision, S.M.; project administration, S.M.; funding acquisition, S.M., A.C.B., K.T.K., K.M.W., T.J.K., and P.B. All authors have read and agreed to the published version of the manuscript.

Funding: This material is based upon work supported by the National Science Foundation under Grant No. 1821566. Any opinions, findings, and conclusions, or recommendations expressed in this material are those of the authors and do not necessarily reflect the views of the National Science Foundation.

Institutional Review Board Statement: The study was conducted according to the guidelines of the Declaration of Helsinki, and approved by the Institutional Review Board of University of Wyoming (protocol code \#20191101TK02576 approved 1 November 2019).

Informed Consent Statement: Informed consent was obtained for all subjects involved in the study.

Data Availability Statement: The data presented in this study are available on request from the corresponding author. The data are not publicly available due to confidentiality of subjects.

Conflicts of Interest: The authors declare no conflict of interest.

\section{References}

1. Liepertz, S.; Borowski, A. Testing the consensus model: Relationships among physics teachers' professional knowledge, interconnectedness of content structure and student achievement. Int. J. Sci. Educ. 2019, 41, 890-910. [CrossRef]

2. Sheppard, K.; Padwa, L.; Kelly, A.M.; Krakehl, R. Out-of-Field teaching in chemistry and physics: An empirical census study. J. Sci. Teach. Educ. 2020. [CrossRef]

3. Hofstein, A.; Lunetta, V.N. The role of the laboratory in science teaching: Neglected aspects of research. Rev. Educ. Res. 1982, 52, 201-207.

4. Kaden, U. COVID-19 school closure related changes to the professional life of a K-12 teacher. Educ. Sci. 2020, 10, 165. [CrossRef]

5. Khanal, P.; Bento, F.; Tagliabue, M. A scoping review of organizational responses to the covid-19 pandemic in schools: A complex systems perspective. Educ. Sci. 2021, 11, 115. [CrossRef]

6. Palloff, R.M.; Pratt, K. The Virtual Student: A Profile and Guide to Working with Online Learners; Jossey-Bass: San Francisco, CA, USA, 2003; pp. 1-191.

7. Smith, P.L.; Ragan, T.J. Instructional Design, 3rd ed.; Wiley: Hoboken, NJ, USA, 2005; pp. 1-383.

8. Rice, K. Making the Move to K-12 Online Teaching: Research-Based Strategies and Practices; Pearson: Boston, MA, USA, 2012; pp. 1-270.

9. Lehman, R.M.; Berg, R.A. 147 Practical Tips for Synchronous and Blended Technology Teaching and Learning; Atwood Publishing: Madison, WI, USA, 2007; pp. 1-104.

10. Kilty, T.J.; Burrows, A.C. Secondary Science Preservice Teachers' Perceptions of Engineering: A Learner Analysis. Educ. Sci. 2019, 9, 29. [CrossRef]

11. Ally, M. Foundations of educational theory for online learning. In The Theory and Practice of Online Learning, 2nd ed.; Anderson, T., Ed.; AU Press: Edmonton, AB, Canada, 2008; pp. 15-44.

12. Jeschofnig, L.; Jeschofnig, P. Teaching Lab Science Courses Online: Resources for Best Practices, Tools, and Technology; Jossey-Bass: San Francisco, CA, USA, 2011; pp. 1-176.

13. Lim, C.P. Formulating guidelines for instructional planning in technology enhanced learning environments. J. Interact. Learn. Res. 2009, 20, 55-74.

14. Martinez, M.E.; Peters Burton, E.E. Cognitive affordances of the cyberinfrastructure for science and math learning. Educ. Media Int. 2011, 48, 17-26. [CrossRef]

15. Mawn, M.V.; Carrico, P.; Charuk, K.; Stote, K.S.; Lawrence, B. Hands-on and online: Scientific explorations through distance learning. Open Learn. 2011, 26, 135-146. [CrossRef]

16. Jarvis, C.; Dickie, J. Podcasts in support of experiential field learning. J. Geogr. High. Educ. 2010, 34, 173-186. [CrossRef]

17. Powell, C.B.; Mason, D.S. Effectiveness of podcasts delivered on mobile devices as a support for student learning during general chemistry laboratories. J. Sci. Educ. Technol. 2013, 22, 148-170. [CrossRef]

18. Hu, S.; Torphy, K.T.; Evert, K.; Lane, J.L. From Cloud to Classroom: Mathematics Teachers' Planning and Enactment of Resources Accessed within Virtual Spaces. Teach. Coll. Rec. 2020, 122, n6.

19. Gordon, S.P.; Jacobs, J.; Croteau, S.M.; Solis, R. Informal teacher leaders: Who they are, what they do, and how they impact teaching and learning. J. Sch. Leadersh. 2020. [CrossRef]

20. Martins Gomes, D.; McCauley, V. Creativity in science: A dilemma for informal and formal education. Sci. Educ. 2021, 105, 498-520. [CrossRef] 
21. Evans, P.K.; McAlister-Shields, L.; Manuel, M.; Stokes, D.W.; Nguyen, H.; Craig, C.J. Examining the Impact of Informal Experiences on Preservice Teachers' Self-efficacy. In Preparing Teachers to Teach the STEM Disciplines in America's Urban Schools; Emerald Group Publishing: Bingley, UK, 2021.

22. Shiri, A.; Borji, Z. Examining the Perceptions and Experiences of Novice Teachers from the Process of Formal and Informal Identification. J. Manag. Plan. Educ. Syst. 2020, 13, 57-94.

23. Walton, G.; Matthews, G. (Eds.) Exploring Informal Learning Space in the University: A Collaborative Approach; Routledge: Milton Park, Oxfordshire, UK, 2017.

24. Viberg, O.; Andersson, A.; Wiklund, M. Designing for sustainable mobile learning-re-evaluating the concepts "formal" and "informal". Interact. Learn. Environ. 2021, 29, 130-141. [CrossRef]

25. Denny, M. Weather balloon ascent rate. Phys. Teach. 2016, 54. [CrossRef]

26. Lally, V.E. Balloons for science. Phys. Teach. 1982, 20. [CrossRef]

27. Larson, S.L.; Armstrong, J.C.; Hiscock, W.A. The first frontier: High altitude ballooning as a platform for student research experiences in science and engineering. Am. J. Phys. 2009, 77. [CrossRef]

28. Saba, M.M.F.; Mirisola, L.G.B.; Iguchi, M. A low-cost sounding balloon experiment. Phys. Teach. 2005, 43. [CrossRef]

29. Fong, B.N.; Kennon, J.T.; Robers, E. Integrating balloonSAT and atmospheric dynamic concepts into the secondary classroom. Phys. Teach. 2016, 54. [CrossRef]

30. Merhar, V.K.; Capuder, R.; Maroševic, T.; Artac, S.; Mozer, A.; Štekovic, M. Vic goes to near space. Phys. Teach. 2016, 54. [CrossRef]

31. Spuck, T. Putting the "authenticity" in science learning. In Einstein Fellows: Best Practices in STEM Education; Spuck, T., Jenkins, L., Dou, E., Eds.; Peter Lang: Bern, Switzerland, 2014; pp. 118-156.

32. Boschman, F.; McKenney, S.; Voogt, J. Understanding decision making in teachers' curriculum design approaches. Educ. Tech. Res. Dev. 2014, 62, 393-416. [CrossRef]

33. Koeppen, K.E. The experiences of a secondary Social Studies student teacher: Seeking security by planning for self. Teach. Teach. Educ. 1998, 14, 401-411. [CrossRef]

34. Koro-Ljungberg, M.; Yendol-Hoppey, D.; Smith, J.J.; Hayes, S.B. (E)pistemological awareness, instantiation of methods, and uninformed methodological ambiguity in qualitative research projects. Educ. Res. 2009, 38, 687-699. [CrossRef]

35. Stake, R.E. The Art of Case Study Research; Sage: Thousand Oaks, CA, USA, 1995; pp. 1-175.

36. Burrows, A.C.; Garofalo, J.; Barbato, S.; Christensen, R.; Grant, M.; Kinshuk; Parrish, J.; Thomas, C.; Tyler-Wood, T. Integrated STEM and Current Directions in the STEM Community. Contemp. Issues Technol. Teach. Educ. 2017, 17, 478-482.

37. Kilty, T.; Burrows, A.; Welsh, K.; Kilty, K.; McBride, S.; Bergmaier, P. Transcending disciplines: Engaging college students in interdisciplinary research, integrated STEM, and partnerships. J. Tech. Sci. Educ. 2021, 11, 146-166. [CrossRef]

38. NGSS Lead States. Next Generation Science Standards: For. States, by States; The National Academies Press: Washington, DC, USA, 2013.

39. Stratostar. Mission Control: UW Space Grant. Available online: https://tracking.stratostar.net/\#!/missions/5f8d26684c135400162 ffbe2 (accessed on 28 October 2020).

40. Wyoming NASA Space Grant. The LIFT Project: GPS Radio Occultation Project. 2021. Available online: http://wyomingspacegrant. org/balloonprogram/liftproject/ (accessed on 22 April 2021).

41. Slater, T.F.; Burrows, A.C.; French, D.A.; Sanchez, R.A.; Tatge, C.B. A proposed astronomy learning progression for remote telescope observation. J. Coll. Teach. Learn. 2014, 11, 197-206. [CrossRef]

42. University of Colorado Boulder. PhET Interactive Simulations. 2021. Available online: https:// phet.colorado.edu (accessed on 22 April 2021).

43. Trustees of Dartmouth College. Remote Lab. Activities and Experiences. 2021. Available online: https://sites.dartmouth.edu/ teachremote/remote-lab-activities-and-experiences/ (accessed on 31 March 2021). 